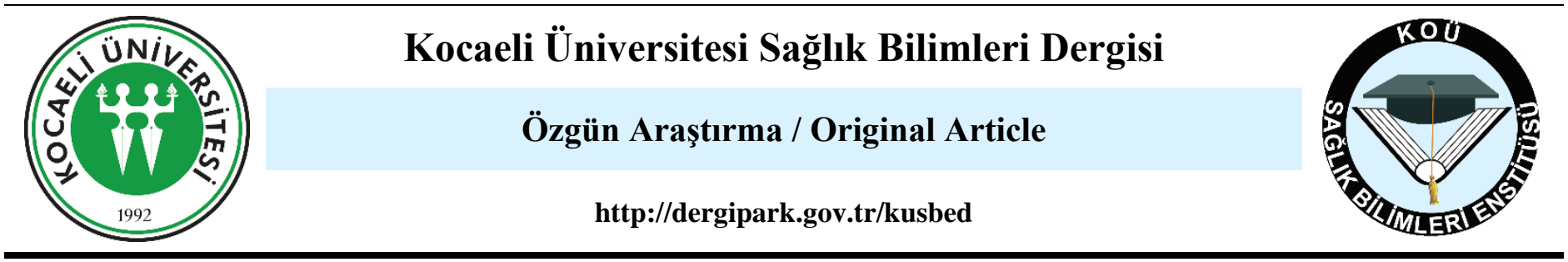

\title{
INFLUENCES OF CHRONIC SMOKING AND ALCOHOL COMSUMPTION ON OXYTOCIN- AND DILTIAZEM-INDUCED FUNCTIONAL RESPONSES OF PREGNANT RAT MYOMETRIUM
}

\author{
KRONIK SIGARA VE ALKOL MARUZIYETININ GEBE RAT MIYOMETRIYYUM OKSITOSIN- VE \\ DILTIAZEM-ARACILI FONKSIYONEL YANITLARI ÜZERINE ETKILERI
}

Semil Selcen Göçmez ${ }^{*}$, (Deynep Ece Utkan Korun², ${ }^{1 D}$ Tuğçe Demirtaş Şahin ${ }^{1}$, (Dijen Utkan ${ }^{1}$

${ }^{1}$ Kocaeli University, Faculty of Medicine, Department of Pharmacology, Kocaeli, Turkey; ${ }^{2}$ Acibadem University Department of Gynecology and Obstetrics, In vitro Fertilization Centers, Acibadem Maslak Hospital, İstanbul, Turkey

ORCID iD: Semil Selcen Göçmez: 0000-0001-7341-4907; Zeynep Ece Utkan Korun: 0000-0002-1595-569X; Tuğçe Demirtaş Şahin: 0000-00029158-7294; Tijen Utkan: 0000-0001-5848-3680

*Sorumlu Yazar / Corresponding Author: Semil Selcen Göçmez e-posta / e-mail: selcengmez@yahoo.com

Geliş Tarihi / Received: 18.02 .2021

Kabul Tarihi / Accepted: 06.04.2021

Yaymm Tarihi / Published:29.05.2021

\begin{abstract}
Objective: Smoking and alcohol consumption during pregnancy lead to undesired effects on labor. Although the underlying mechanisms are still poorly understood, impaired functional responses of myometrium may be one of the reasons for these complications. In this study, we investigated the effects of chronic smoking and alcohol consumption on the functional responses of isolated term-pregnant rat myometrium strips.

Methods: 21 Wistar albino rats were divided into three groups: Control; Smoking group, rats exposed to smoke for 12 weeks; Alcohol group, rats were administered ethanol for 12 weeks ( $\mathrm{n}=7$ in each group). The reactivities of myometrial smooth muscle strips obtained from term labor rats were mounted in organ chambers for the recording of isometric tension. The effects of cumulative concentrations of carbachol $\left(10^{-8}-10^{-4} \mathrm{M}\right)$, oxytocin $\left(10^{-9}-10^{-3} \mathrm{M}\right)$, and diltiazem $\left(10^{-8}-10^{-4} \mathrm{M}\right)$ on myometrial spontaneous contractions were measured.

Results: The amplitude and frequency of carbachol contractile responses decreased in the alcohol group, whereas it significantly increased in the smoking group. The frequency of oxytocin-induced myometrial contractions was significantly increased by smoking, while the amplitude of contractions was not changed. Oxytocin responses as amplitude and frequency of contractions decreased in the alcohol group. There were no significant differences between relaxant responses to diltiazem in both group compared to the controls.

Conclusion: These findings show that smoking may lead to premature labor and alcohol consumption may prolong gestation length by changing contractile and relaxant responses in myometrial smooth muscle. Diltiazem may have a beneficial effect on tocolysis in both conditions during pregnancy.
\end{abstract}

Keywords: Alcohol consumption, Smoking, In vitro, Myometrium, Pregnant, Rat

\section{$\ddot{O} z$}

Amaç: Gebelik sırasında sigara ve alkol tüketimi doğum eylemi üzerinde istenmeyen etkilere neden olmaktadır. Altta yatan mekanizmalar hala tam olarak anlaşılmamış olmakla birlikte, bozulmuş miyometriyum fonksiyonel yanıtları bu komplikasyonların nedenlerinden biri olabilir. Bu çalışmada, kronik sigara ve alkol tüketiminin izole term-gebe siçan miyometriyum şeritlerinin fonksiyonel yanıtlarına etkisini araştırdık.

Yöntem: 21 Wistar albino sıçanı üç gruba ayrıldı: Kontrol; Sigara grubu, sıçanlar 12 hafta boyunca sigara dumanına maruz kaldı; Alkol grubu, sıçanlara 12 hafta boyunca etanol uygulandı $(n=7$, her bir grupta). Doğum dönemlerinde bulunan sıçanlardan izole edilen miyometriyal düz kas şeritleri, izometrik kayıt almak üzere organ banyosuna yerleştirildi. Karbakol $\left(10^{-8}-10^{-4} \mathrm{M}\right)$, oksitosin $\left(10^{-9}-10^{-3} \mathrm{M}\right)$ ve diltiazem $\left(10^{-8}-10^{-4} \mathrm{M}\right)$ kümülatif konsantrasyonlarının miyometriyal spontan kasılmalar üzerindeki etkileri ölçüldü.

Bulgular: Karbakol kasılma yanıtlarının amplitüd ve frekansları sigara grubunda anlamlı olarak artarken, alkol grubunda azaldı. Oksitosin ile indüklenen miyometriyal kasılmaların frekansı sigara maruziyetiyle artarken, kasılmaların amplitüdü değişmedi. Amplitüd ve frekans olarak oksitosin kasılmaları alkol grubunda azaldı. Her iki grupta da diltiazem gevşeme yanıtları arasında kontrollerine göre anlamlı olarak fark yoktu.

Sonuç: Bu bulgular miyometriyal düz kasının kasılma ve gevşeme yanıtlarını değiştirmek yoluyla, sigara maruziyetinin erken doğuma neden olabileceğini ve alkol maruziyetinin gebelik süresini uzatabileceğini göstermektedir. Diltiazem gebelikte her iki durumda da tokoliz için yararlı bir etkiye sahip olabilir.

Anahtar Kelimeler: Alkol Tüketimi, Sigara İçme, İn vitro, Miyometriyum, Gebe, Şıçan 


\section{Introduction}

Several women still continue habitual smoking and alcohol consumption during pregnancy, although abundant evidence clearly indicates adverse effects on especially birth outcomes. Despite a considerable amount of public health effort, at least $12 \%$ of women keep alcohol consumption, while approximately $13-17 \%$ of women smoke during pregnancy. ${ }^{1}$ It was previously reported that smoking is associated with spontaneous abortion, preterm labor, and pregnancy delivery. ${ }^{2}$ The studies on maternal alcohol consumption mainly focus on fetal anomalies. ${ }^{3}$ However, it has also been shown in fewer studies that alcohol consumption alters the length of gestation based on the pattern of consumption and timing exposure in pregnancy.

Preterm labor's pathogenic mechanisms were demonstrated to share a common final pathway leading to a myometrial contraction in clinical and experimental studies. It is well known that oxytocin is a principal hormone that induces uterine smooth muscle contractions and has been utilized to induce delivery or terminate the pregnancy. ${ }^{4,5}$ Limited data indicate a correlation between increased oxytocin receptor expression and increased sensitivity to oxytocin in pregnant rat myometrium and premature human myometrium exposed by smoking or chronic smoke exposure. ${ }^{6-8}$ However, it is needed to design further studies because of the limitation of acute or in vitro cigarette smoke exposure techniques in the previous studies. On the other hand, in clinical and preclinical previous studies, it was indicated that chronic alcohol consumption prolongs the onset of delivery, whereas acute consumption leads to premature birth. ${ }^{9-11}$ It was shown that decreased maternal oxytocin and prostaglandin levels had resulted in the prolongation of the onset of labor and delivery in chronic alcohol consumption. 10,12-14 Although it is reasonable to assess the effect of chronic alcohol consumption on myometrial contractility during pregnancy, it has not been yet studied up to date. Therefore, we treated rats with chronic smoking or alcohol consumption model before and during pregnancy and evaluated whether these treatments are due to direct action on the myometrial contractility to oxytocin and carbachol under non-hormonal conditions in the present study. In addition, we investigated the relaxant effects of diltiazem on myometrial contractility with the same non-hormonal system since calcium channel blockers show great promise in treatment of preterm labor. ${ }^{15}$

There is very limited data about the effects of smoking and alcohol consumption on myometrial relaxant or contractile responses, which is essential for a healthy fetal environment, despite these consumptions during pregnancy are well known to result in birth complications. In this background, this research aimed to evaluate the effects of chronic smoking and alcohol consumption on myometrial contractions and relaxations in isolated strips from term pregnant rats.

\section{Methods}

\section{Animals and experimental designs}

Experiments were performed on Wistar albino rats on the 19th or 21st day of gestation (term-pregnant rat), weighing 180-220 g obtained from the Experimental Medical Research and Application Center (DETAB, Kocaeli University, Kocaeli). Ethics committee approval was granted by the Animal Research Ethics Committee at
Kocaeli University (Kocaeli, Turkey, Project number: KOU HADYEK 6/11-2011). Rats were housed in a temperatureand humidity-controlled room with water and food ad libitum $\left(22 \pm 3{ }^{\circ} \mathrm{C}\right.$ and $62 \pm 7 \%$, respectively) in which a 12 $12 \mathrm{~h}$ light-dark cycle was maintained (08:00-20:00 h light). Female Wistar albino rats were individually housed in a metal cage and were randomly divided into four groups; controls $(n=7)$ (different animals were used for alcohol and smoking groups, separately), cigarette smoking $(n=7)$, and alcohol consumption group $(n=7)$. The experiments were conducted with two experimental protocols: control and smoking groups were used for experiment 1 , and control and alcohol groups were set up as experiment 2. The experimental protocol of secondhand smoking was carried out according to a previous study. ${ }^{16}$ The rats were placed in a glass cage and inhaled smoke from 4 cigarettes for $30 \mathrm{~min}$ twice daily over 12 -weeks (smoking rats). Rats were put in separate cages at the end of the exposure period. The last smoking was performed $18 \mathrm{~h}$ before the experiments. Rats were also placed in the same cage without cigarette smoke and inspired fresh air in the control group. The model of alcohol consumption was performed according to a study described previously. ${ }^{17}$ The rats received $5 \%$ ethanol $(\mathrm{vol} / \mathrm{vol})$ in the drinking water for the first week, $10 \%$ for the next two weeks, $20 \%$ from weeks 4-12. The control was fed up water ad libitum, and all rats had constant access to standard laboratory rat chow. Virgin female rats with one male were placed in cages separately for 24 hours within the last 3 weeks of smoking or alcohol consumption period. Vaginal plugs were examined in the vaginal smear specimen on the next morning of pairing. The day that spermatozoa in the vaginal smears were obtained was designated as day 0 of gestation. In previous studies, the uteri of pregnant rats was obtained from 21 days of pregnancy and they were used to measure myometrial contractility as the pregnant myometrium. ${ }^{5}$

Urine samples were collected at the end of the 12-week by putting the animals in metabolic cages for 24 hours and urine cotinine and nicotine metabolite levels determined by radioimmunoassay (RIA) in secondhand smoking (SHS) exposure group. Ethanol concentration in blood was assessed by $\mathrm{NAD}^{+} / \mathrm{NADH}$ enzyme-spectrophotometric method. Arterial blood samples were taken from anesthetized rats at the time of the experiment.

\section{Measurement of myometrial contractile activity}

As previously described, the rats were killed by a cervical subluxation at 19 th or 21 th day of gestation. ${ }^{18,19}$ Myometrial strips (approximately $8 \mathrm{~mm} \times 2 \mathrm{~mm} \times 2 \mathrm{~mm}$ ) were isolated from the middle of uterine horns in the longitudinal direction. The strips were immediately placed and mounted in the organ chambers for isometric tension measurement in modified Kreb's buffer ( $\mathrm{NaCl} 125 \mathrm{mM}, \mathrm{KCl} 2.4 \mathrm{mM}, \mathrm{CaCl}_{2}$ $1.8 \mathrm{mM}, \mathrm{MgCl}_{2} 0.5 \mathrm{mM}, \mathrm{NaHCO}_{3} 23.9 \mathrm{mM}$, and glucose 11 $\mathrm{mM}$ ) aerated with a gas mixture of $95 \% \mathrm{O} 2$ and $5 \% \mathrm{CO} 2$ $(\mathrm{pH}=7.4)$. Muscle contractions were recorded using a transducer (TRI 202P, Letica Scientific Instruments, Italy) on a polygraph system (Polygraph model 2000-506, Letica Scientific Instruments, Italy). Recording of isometric strip tension was made using a transducer (TRI 202P, Letica Scientific Instruments, Italy) and recorded on a polygraph system (Polygraph model 2000-506, Letica Scientific Instruments, Italy). After mounting, each strip was allowed to set with a basal tension of $1 \mathrm{~g}$ for $1 \mathrm{~h}$, as previously found to be optimal for the measurement of changes in the contractility of rat myometrial tissue preparations. The 
tissue bath solution was replaced every 15 min during this period.

The calibration of the recorder was adjusted so that $1 \mathrm{~g}$ tension performed as $1 \mathrm{~cm}$ vertically. Paper speed was determined as $3 \mathrm{~mm} / \mathrm{min}$. Three sets of experiments were conducted with myometrial strips, and each drug was tested on one of the strips. The effects of carbachol $\left(10^{-8}-10^{-4} \mathrm{M}\right)$, oxytocin $\left(10^{-9}-10^{-3} \mathrm{M}\right)$, and diltiazem $\left(10^{-8}-10^{-4} \mathrm{M}\right)$ on spontaneous contractions of the control, smoking, and alcohol group myometrial strips were evaluated, respectively. Then the strips were washed with fresh buffer. Spontaneous contractions of the strips were again measured at the end of each experiments.

\section{Drugs}

The following drugs were all obtained from Sigma Chemical (St. Louis, MO, USA): carbachol chloride, oxytocin, and diltiazem. All drugs dissolved in distilled water and were freshly prepared on the day of the experiment.

\section{Statistical analysis}

Data analysis was applied as previously described. ${ }^{19}$ Briefly, the amplitude and frequency of spontaneous myometrial contractions were measured and regarded as a reference response at the beginning of each experiment. After the addition of each drug concentration, alterations in the spontaneous myometrial contractions were measured for 300 s intervals. Values of amplitude (g) and frequency (number/min) for these intervals were expressed as percentages of the initial reference responses. The results are expressed as the mean $\pm \mathrm{SE}$ of different experiments. Statistical comparison between experimental groups was analyzed using ANOVA with $t$-test. Probabilities of $p<0.05$ were considered statistically significant. All statistical analyzes were performed using Graphpad Prism 4 (Graphpad Software Inc., CA, USA) computer program.

\section{Results}

The urine nicotine metabolite and blood ethanol concentrations of all groups at the end of 12 weeks are shown in Tables 1 and 2. The nicotine and ethanol levels were significantly increased in the smoking and alcohol groups compared with the control group, respectively $(p<0.05)$.

Carbachol and oxytocin concentration-dependently increased spontaneous contractile activity in myometrial smooth muscle isolated from pregnant rats. Figure 1 demonstrates representative recordings of the effects of oxytocin-stimulated contractions of myometrial strips isolated from term pregnant rats (Figure 1). The mean values of the amplitude and frequency data of rats' spontaneous myometrial contractions are listed in Table 3. The amplitude and frequency of contraction with carbachol were significantly higher in smoking group strips as compared with control strips at $10^{-7}-10^{-4} \mathrm{M} \quad(p<0.05)$. Carbachol, beginning from $10^{-6}$ and $10^{-4} \mathrm{M}$, significantly decreased the amplitude and frequency of contractions in alcohol group strips $(p<0.05)$. Figures 2 and 3 summarise the data for the effects of increasing concentrations of carbachol stimulated contractions of myometrial strips isolated from term pregnant smoking and alcohol consuming rats, respectively.

Oxytocin, there was no significant difference in the amplitude of contractions between normal and smoking group strips, whereas the frequency of contraction was significantly higher in the smoking group as compared with normal strips beginning from $10^{-8} \mathrm{M} \quad(p<0.05)$. The contractile responses as amplitude and frequency values significantly reduced in the alcohol group comparing with control strips at the concentration between $10^{-8}-10^{-3} \mathrm{M}$ for oxytocin $(p<0.05)$. Figures 4 and 5 summarize the data for the effects of increasing concentrations of oxytocinstimulated contractions of myometrial strips isolated from term pregnant smoking and alcohol consuming rats, respectively.

Diltiazem $\left(10^{-8}-10^{-4} \mathrm{M}\right)$ concentration-dependently inhibited myometrial contractions. The inhibitor effect of diltiazem was similar in all myometrial tissues. The decreased amplitude and frequency of the contractile responses did not change in strips from the smoking group. The amplitude and frequency of contractions were suppressed in the concentrations between $10^{-7}-10^{-5} \mathrm{M}$ as compared with control $(p<0.05)$ in alcohol group. Figures 6-7 summarizes the data for the effects of increasing concentrations of diltiazem stimulated relaxations of myometrial strips isolated from term pregnant smoking and alcohol consuming rats, respectively.

After concentration-response curves were completed in each experiment, the tissues were washed out with fresh buffer for obtaining the beginning levels of spontaneous contractions (Figures 2-7).

Table 1. The urine levels of nicotine metabolites (ng/ml)

\begin{tabular}{|l|l|l|l|}
\hline Control & n & Smoking & n \\
\hline $234.86 \pm 32.5$ & 7 & $5755.9 \pm 2327.3^{*}$ & 7 \\
\hline
\end{tabular}

$* p<0.05$, statistically different from control rats.

Table 2. The blood levels of ethanol (mg/dl)

\begin{tabular}{|l|l|l|l|}
\hline Control & n & Alcohol & n \\
\hline None detectable & 7 & $26.2 \pm 2.99 *$ & 7 \\
\hline
\end{tabular}

${ }^{*} p<0.05$, statistically different from control rats.

Table 3. Amplitude and frequency data of spontaneous myometrial contractions of pregnant rat

\begin{tabular}{|l|l|l|l|l|l|l|}
\hline & Control & n & Smokig & n & Alcohol & n \\
\hline Mean Amplitude (g) & $4.62 \pm 0.39$ & 7 & $4.64 \pm 0.42$ & 7 & $4.43 \pm 0.23$ \\
\hline $\begin{array}{l}\text { Frequency } \\
\text { (number/300 s) }\end{array}$ & $9 \pm 0.78$ & 7 & $9.28 \pm 0.64$ & 7 & $9.14 \pm 0.74$ \\
\hline
\end{tabular}

Data expressed as mean \pm SE. 


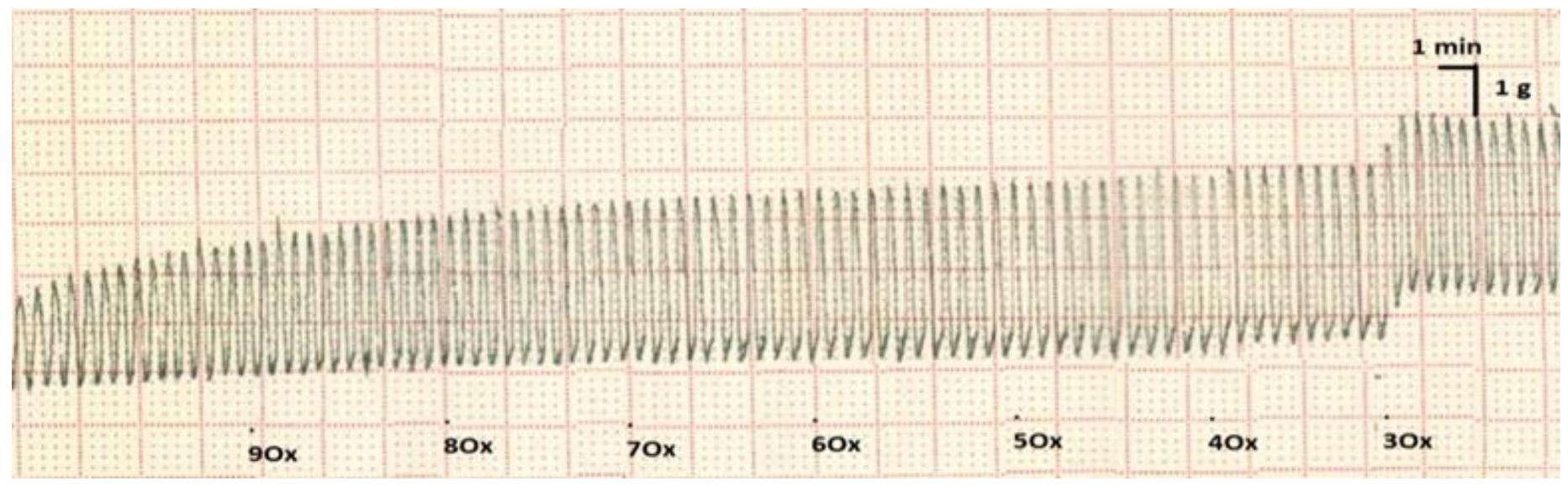

a)
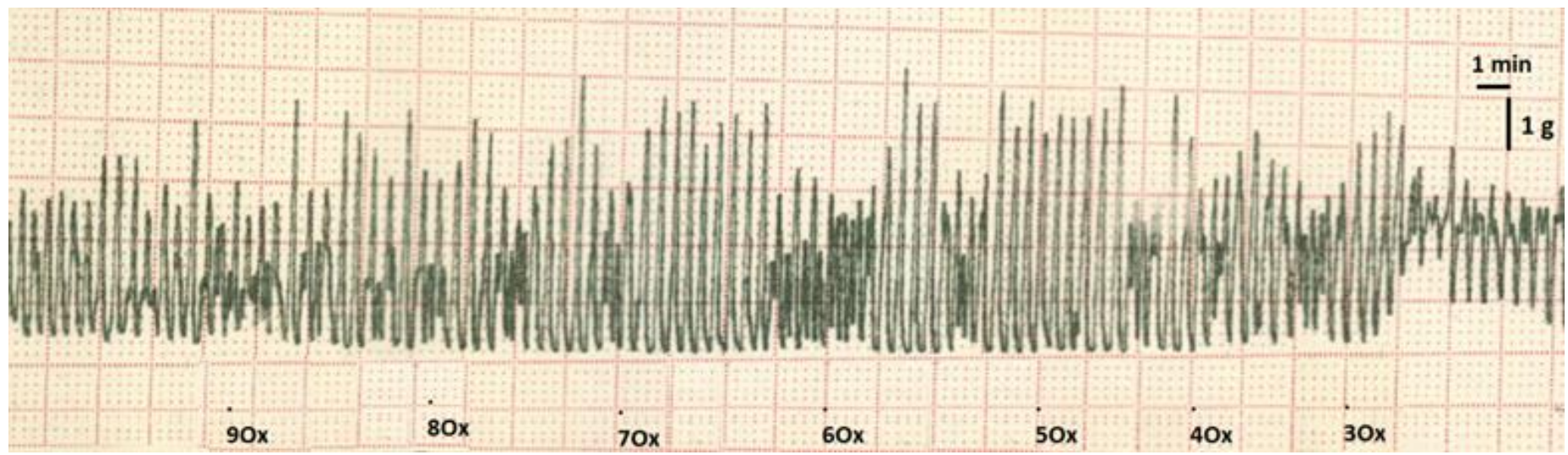

b)

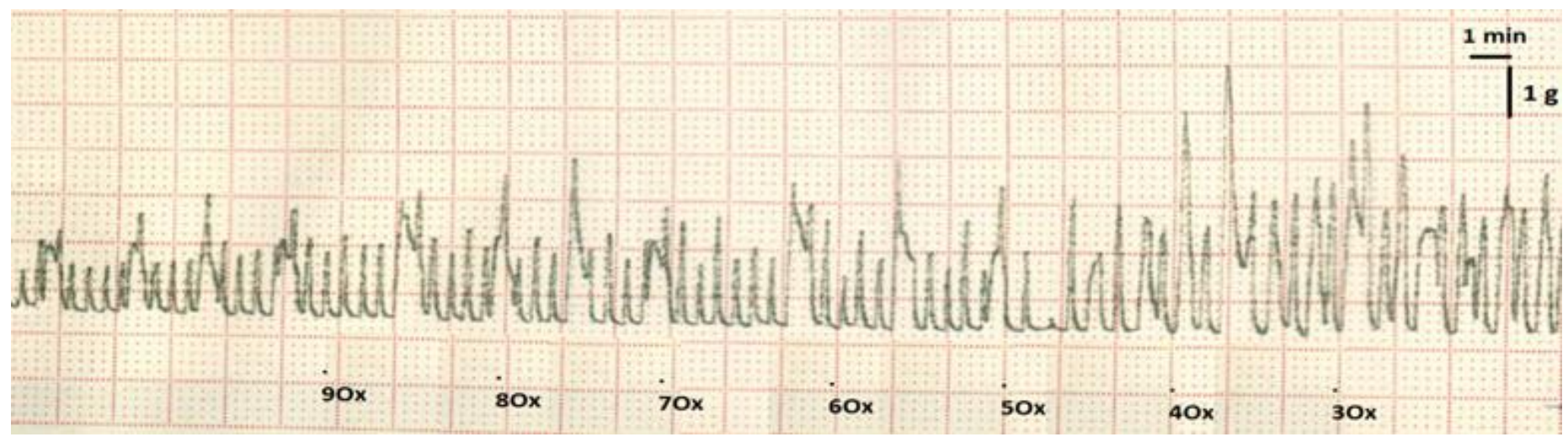

c)

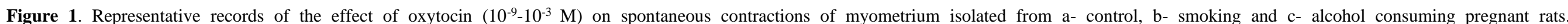



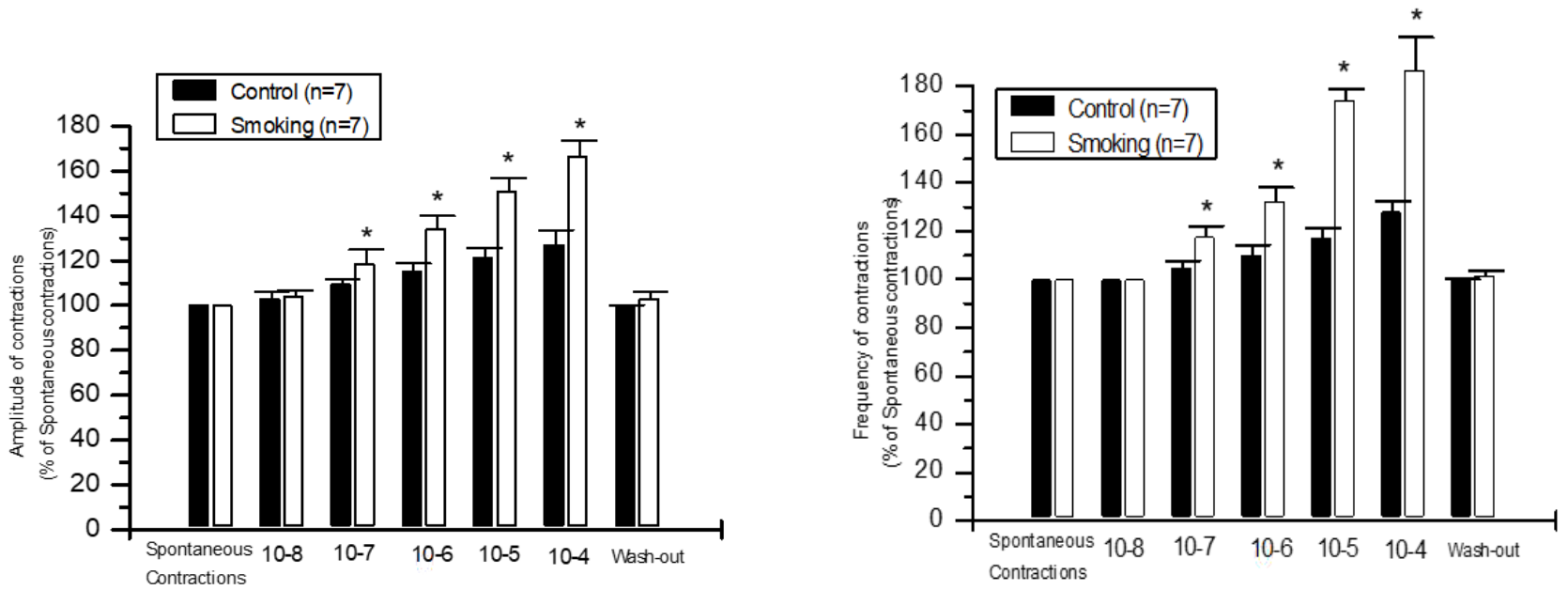

a)

b)

Figure 2. Effect of $10^{-8}-10^{-4} \mathrm{M}$ carbachol on the a- amplitude and b- frequency of spontaneous contractions of myometrium isolated from pregnant control $(\mathrm{n}=7)$ and smoking $(\mathrm{n}=7)$ rat. Data (mean $\pm \mathrm{SE})$ are expressed relative to controls (initial spontaneous contractions) $(* p<0.05)$.
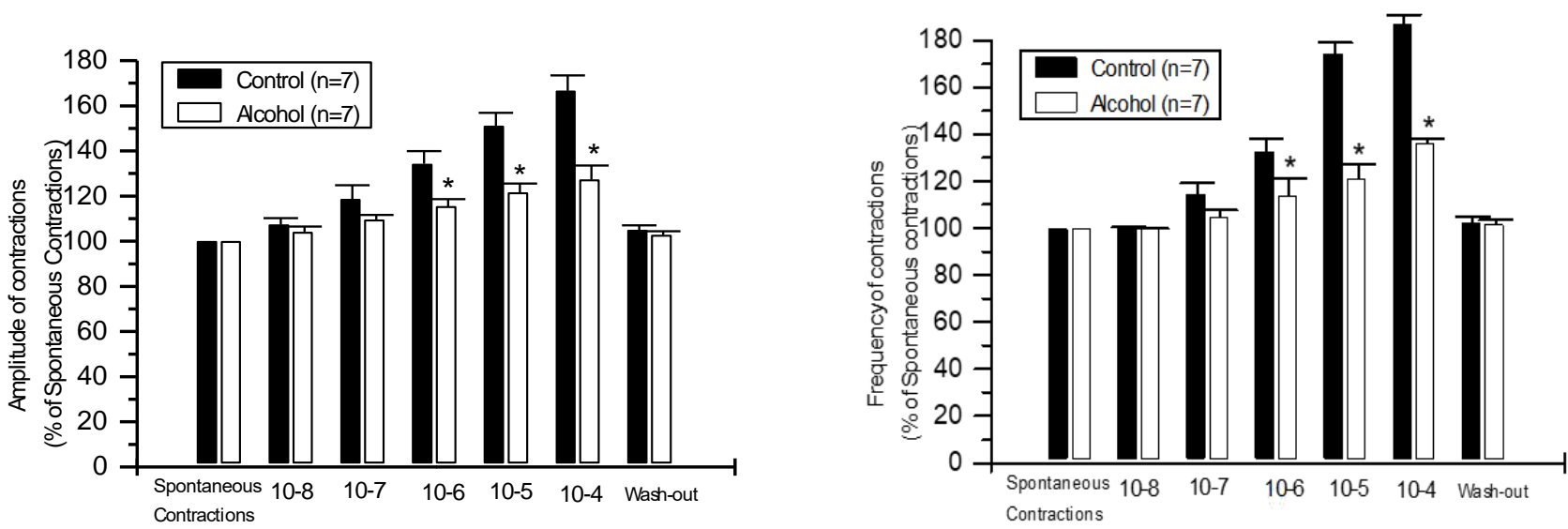

a)

b)

Figure 3. Effect of $10^{-8}-10^{-4} \mathrm{M}$ carbachol on the a- amplitude and b- frequency of spontaneous contractions of myometrium isolated from pregnant control $(n=7)$ and alcohol consuming $(n=7)$ rat. Data (mean $\pm S E)$ are expressed relative to controls (initial spontaneous contractions) $(* p<0.05)$.

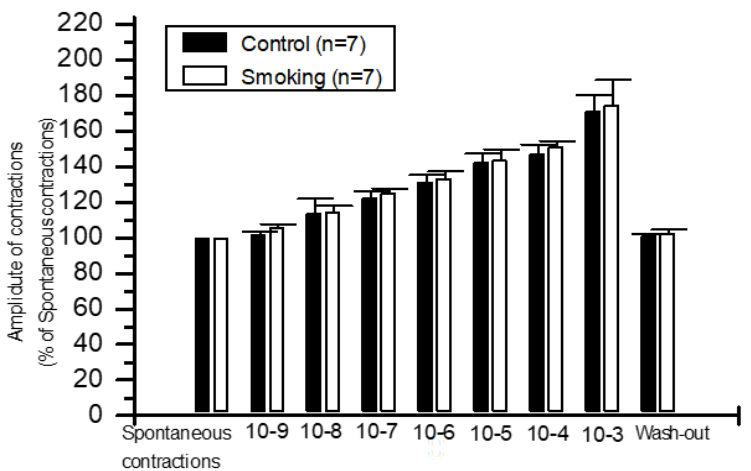

a)

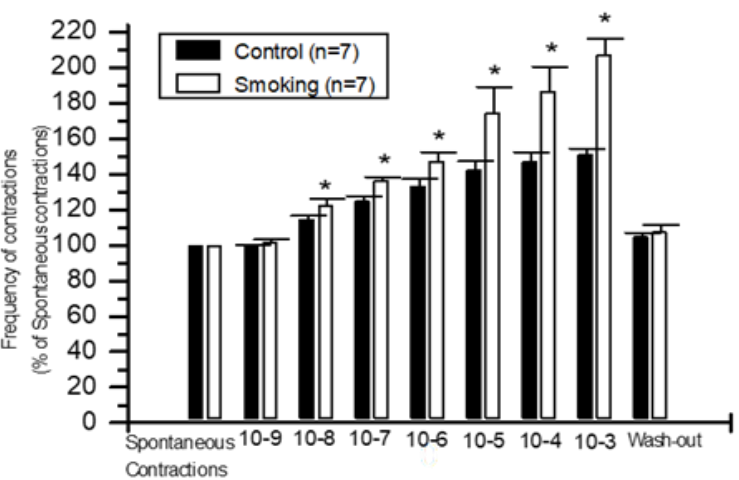

b)

Figure 4. Effect of $10^{-9}-10^{-3} \mathrm{M}$ oxytocin on the a- amplitude and b- frequency of spontaneous contractions of myometrium isolated from pregnant control $(\mathrm{n}=7)$ and smoking $(\mathrm{n}=7)$ rat. Data (mean $\pm \mathrm{SE})$ are expressed relative to controls (initial spontaneous contractions) $(* p<0.05)$. 

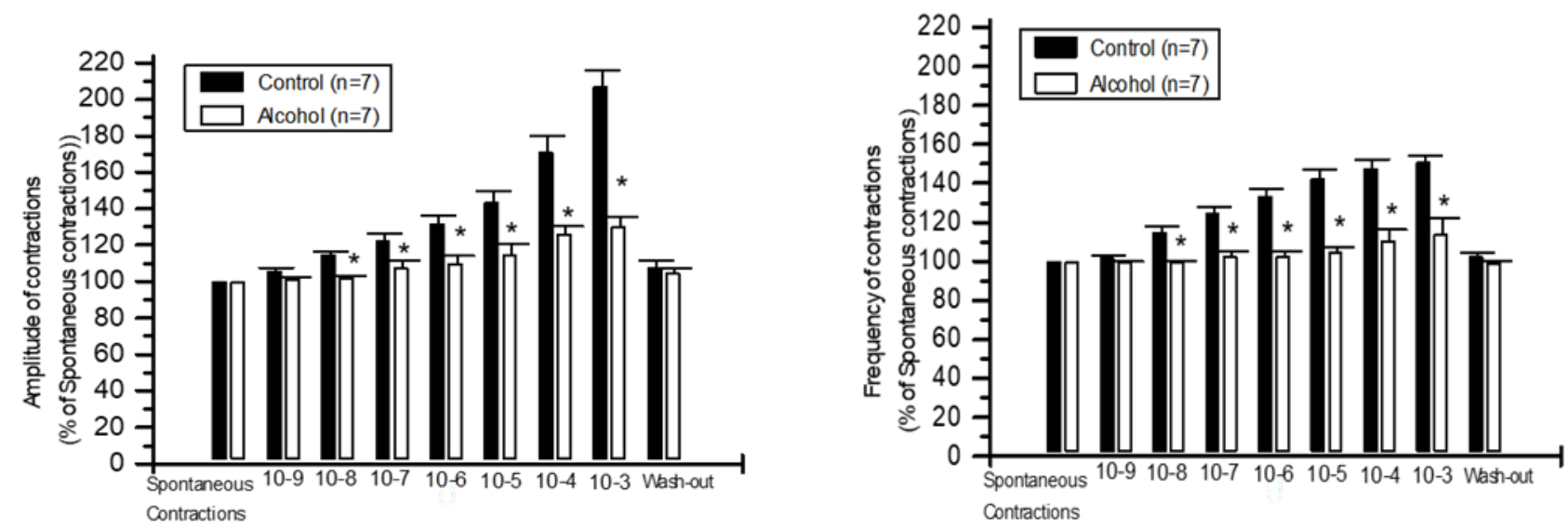

a)

b)

Figure 5. Effect of $10^{-9}-10^{-3} \mathrm{M}$ oxytocin on the a- amplitude and b- frequency of spontaneous contractions of myometrium isolated from pregnant control $(\mathrm{n}=7)$ and alcohol consuming $(\mathrm{n}=7)$ rat. Data (mean \pm SE) are expressed relative to controls (initial spontaneous contractions) $(* p<0.05)$.

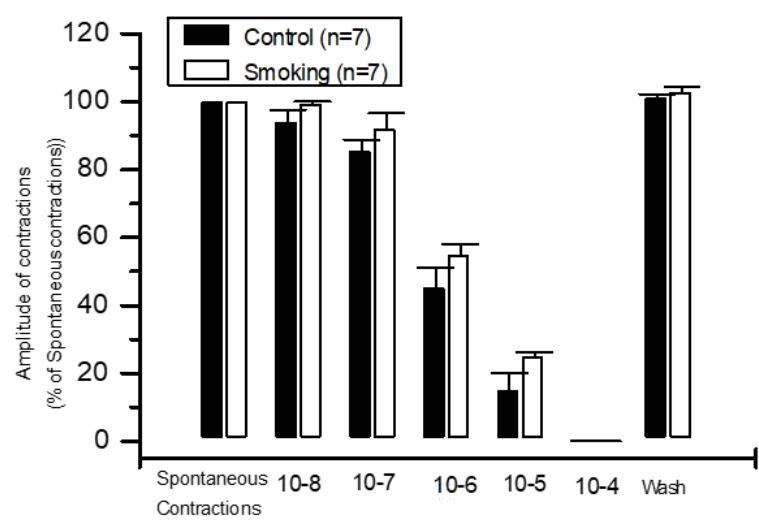

a)

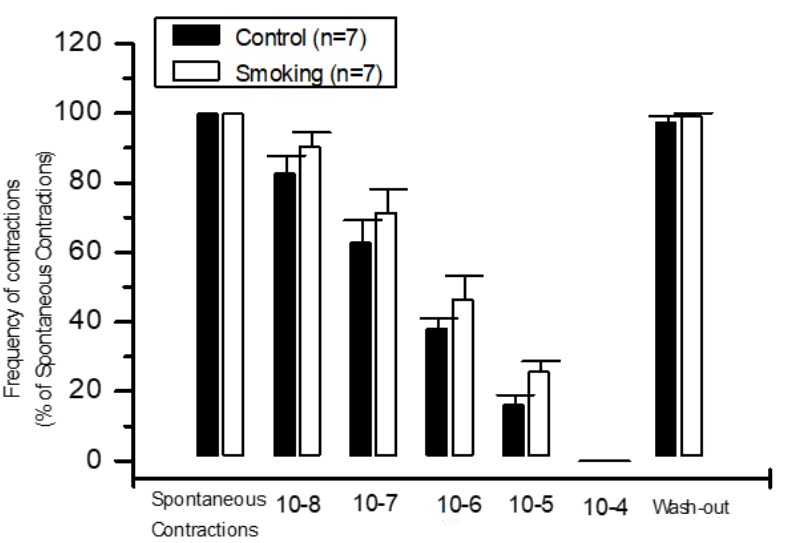

b)

Figure 6. Effect of $10^{-8}-10^{-4} \mathrm{M}$ diltiazem on the a- amplitude and b- frequency of spontaneous contractions of myometrium isolated from pregnant control $(\mathrm{n}=7)$ and smoking $(\mathrm{n}=7)$ rat. Data (mean $\pm \mathrm{SE})$ are expressed relative to controls (initial spontaneous contractions) $(* p<0.05)$.

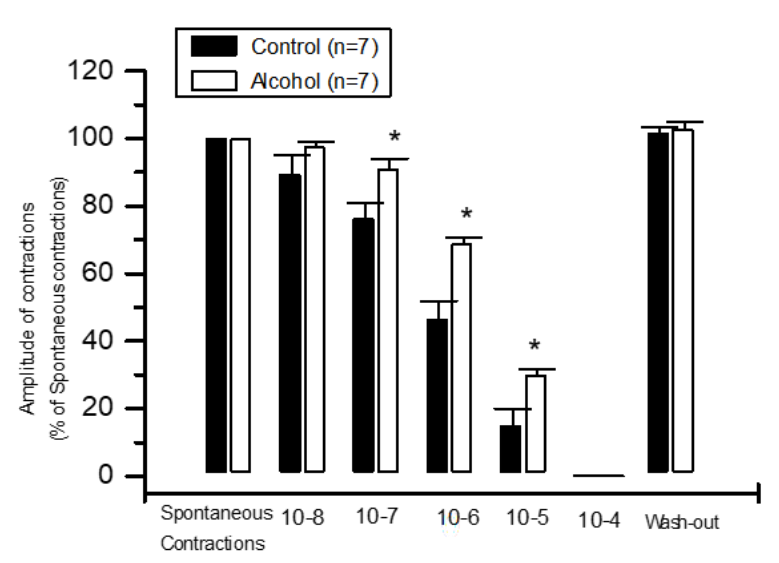

a)

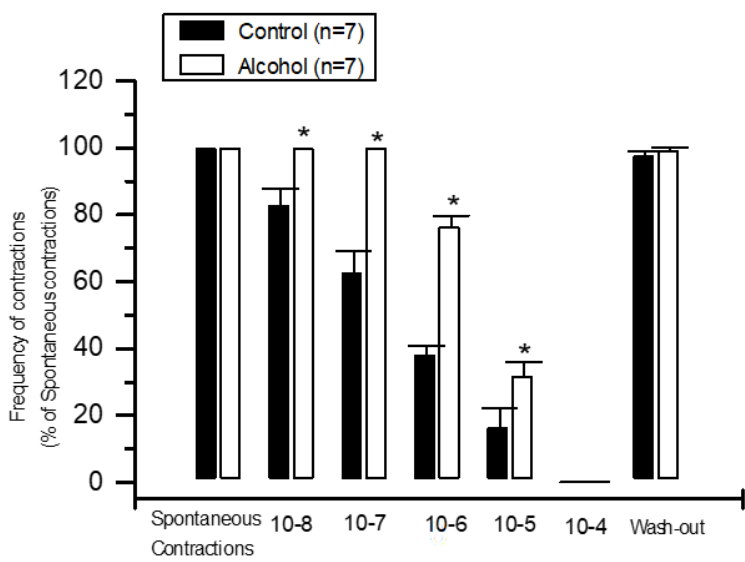

b)

Figure 7. Effect of $10^{-8}-10^{-4} \mathrm{M}$ diltiazem on the a- amplitude and b- frequency of spontaneous contractions of myometrium isolated from pregnant control $(\mathrm{n}=7)$ and alcohol consuming $(\mathrm{n}=7)$ rat. Data (mean \pm SE) are expressed relative to controls (initial spontaneous contractions) $(* p<0.05)$. 


\section{Discussion}

A number of clinical and experimental studies have provided evidence that smoking significantly increases preterm labor incidence. ${ }^{7,8}$ Some clinical and basic studies indicate that alcohol consumption during pregnancy alters the length of gestation. ${ }^{10}$ However, the causal mechanism has not yet been fully understood. In this study, we aimed to investigate the effects of maternal smoking and alcohol consumption on the myometrial contractile function to identify possible mechanisms that may cause altered myometrial activity and dysfunctional labor. The animal model of smoking and alcohol consumption has been validated by measurement of the urine nicotine metabolite and blood ethanol concentrations at the end of 12 weeks. This study indicates that smoking and alcohol consumption impaired both carbachol and oxytocin-induced contractions in the rat myometrium smooth muscle, whereas the relaxant responses to diltiazem, calcium channel blocker, were not affected. The increased contractions of myometrium smooth muscle obtained from the smoking group can contribute to the mechanisms that lead to preterm labor in smoking. On the other hand, decreased contractile functional responses in the alcohol group may contribute to the prolongation length of gestation in alcohol consumption during pregnancy.

It is well known that uterine activity and labor have a closed relationship. The contractions become progressively more frequent before the onset of labor, and they lead to the fetus's delivery as soon as strong enough. Oxytocin has a major role in inducing uterine contractile activity for pregnancy termination and causes myometrial contraction via stimulation of the oxytocin receptors. ${ }^{20}$ It was demonstrated that depolarization of myometrial cells induced by opening calcium-activated chloride and cation channels after stimulation of these receptors and then opened voltage-dependent calcium channels. ${ }^{4}$ Myometrial contraction caused by oxytocin via the oxytocin receptors is also included in preterm labor and delivery. ${ }^{21}$ In our study, oxytocin significantly increased in the myometrial spontaneous contractions in the smoking group. Consistent with our data, there are few studies reported that myometrial contractile sensitivity and activity in response to oxytocin increased in cigarette smoking rats during pregnancy. Their results indicated that increased contractile activity of preterm myometrium to oxytocin were depend on the upregulation of the oxytocin receptors and the increased level of myometrial oxytocin receptors were accompanied by increased risk of preterm labor and delivery. ${ }^{6,8}$ However, in these studies, they have used either a short-term experimental animal model of passive smoking or incubated in vitro myometrium tissues with cigarette smoking extract. There is only one study with smoking pregnant women who smoked at least one cigarette/day in the literature. ${ }^{7}$ In our research, we can speculate that the concentration-dependent increase in amplitude and frequency in response to oxytocin in the smoking group may be explained due to an increase in oxytocin receptor density in the myometrium. In addition, carbachol is another contractile element to induce contractions through G-protein mediated mechanism, significantly increasing the amplitude and frequency of rat myometrial spontaneous contractions in smoking rats. This may contribute to the hypothesis that smoking may result in preterm labor via alteration in contractile characteristics through different mechanisms.
Both clinical and preclinical studies suggest that alcohol consumption during pregnancy causes congenital disabilities and alters gestation length. There are some animal studies show that alcohol results in prolongation of gestational length. By the contrast of these studies, it was suggested that increased preterm delivery incidence was associated with alcohol consumption during pregnancy in a clinical study. ${ }^{14}$ The studies have opposite findings on acute and chronic consumption of alcohol in pregnancy. The studies have opposite findings on acute and chronic consumption of alcohol in pregnancy. Previous studies suggested that chronic consumption prolonged the duration of pregnancy, while acute consumption resulted in increased risk for earlyonset delivery. ${ }^{22,23}$ These findings indicate two important factors caused either delayed or premature delivery: the pattern of consumption and timing of exposure. ${ }^{10,14}$ In previous studies, it was shown that the administration of ethanol led to the inhibition of oxytocin release from the neurohypophysis. ${ }^{12,13}$ According to this data, ethanol may have a possible role in treating premature delivery in humans as a tocolytic agent. Additionally, Cook and Randall (2010) support that ethanol leads to either pre-or post-term delivery depending upon alterations in prostaglandins levels. Their findings showed that chronic ethanol consumption resulted in delayed labor onset due to decreased oxytocin levels accompanied by decreased uterine prostaglandins synthesis. They have suggested that the opposite effects of acute and chronic ethanol consumption on the onset of labor could be, at least in part, dependent on their different effects on uterine prostaglandins levels. ${ }^{10}$ In our study, chronic alcohol consumption impaired contractile responses to oxytocin and carbachol. In this background, decreased contractility of myometrium obtained from alcoholconsuming pregnant rats may be assumed to both inhibited oxytocin release and suppressed uterine prostaglandins synthesis. Although it has not yet been studied the levels of prostaglandins and oxytocin in this study, it is reasonable to speculate that chronic ethanol treatment decrease either prostaglandins and/or oxytocin levels. It is the first time study to investigate the effect of chronic ethanol consumption on in vitro myometrial contractility, but it is needed further studies to enlighten the mechanism of the inhibitory effect of ethanol on uterine contractility.

The density of voltage-dependent calcium channels increases during pregnancy, and they have an important role in myometrial contractility during labor. ${ }^{19,24}$ There are some studies reported that calcium channel blockers have a beneficial effect in preventing preterm labor. ${ }^{18,19,25}$ The calcium channel blockers prevent the extracellular calcium entry through voltage-dependent calcium channels into myometrial smooth muscle cells. In addition, the calcium release from the intracellular sarcolemma is inhibited by the calcium channel blockers. ${ }^{19,26}$ The previous studies have generally focused on dihydropyridines. ${ }^{18,25}$ diltiazem is another voltage-dependent calcium channel blocker and may result in myometrial relaxation via the inhibition of the influx of extracellular calcium ions. In previous clinical reports, it was shown no significant differences in either efficacy or side effects between diltiazem and dihydropyridines as a tocolytic agent. ${ }^{27}$ Our data is accordance with the findings of previous studies on the relaxant effect of calcium channel blockers in myometrium smooth muscle. But it was shown for the first time that there are no significant differences between the maximum 
relaxant responses of diltiazem in smoking, alcohol consuming and normal animals in this study.

In conclusion, our findings suggest that increased contractile response may contribute to the mechanisms leading to preterm labor in smoking. The impaired contractile responses in chronic alcohol-consuming rats may prolong gestation length in this blood level and alcohol exposure time. According to our data, diltiazem may be a therapeutic alternative for tocolytic treatment in both conditions during pregnancy because of the smoking and alcohol group's unchanged relaxant response.

\section{Acknowledgements}

The authors thank to Robert Prem for the Professional linguistic revision of article. This study was presented as an oral presentation in 7 th European Congress of Pharmacology.

\section{Conflict of Interest}

The authors have no conflicts of interest to disclose.

\section{Financial Support}

This study was supported by Research Foundation (NKUBAP.00.20.AR.12.04) by the Namik Kemal University.

\section{Author Contributions}

SSG, TU: Design; SG, ZEUK, TDŞ, TU: Project development; SSG, TDŞ: Data collection; SSG, ZEUK: Literature search; SSG, ZEUK, TDŞ, TU: Data analysis; SSG, ZEUK: Manuscript writing; ZEUK, TU: Critical review

\section{References}

1. Guyer B, Hoyert DL, Martin JA, Ventura SJ, MacDorman MF, Strobino DM. Annual summary of vital statistics-1998. Pediatrics 10.1542/peds.104.6.1229. 1999;104:1229-1246. doi:

2. Kleinman JC, Pierre MB, Madans JH, Land GH, Schramm WF. The effects of maternal smoking on fetal and infant mortality. Am $J$ Epidemiol. 1988;127:274-282. doi: 10.1093/oxfordjournals.aje.a114803.

3. Aliyu MH, Lynch O, Nana PN, Alio AP, Wilson RE, Marty PJ, et al. Alcohol consumption during pregnancy and risk of placental abruption and placenta previa. Matern Child Health J. 2011;15:670-676. doi: 10.1007/s10995-010-0615-6.

4. Arrowsmith S, Wray S. Oxytocin: its mechanism of action and receptor signalling in the myometrium. $J$ Neuroendocrinol. 2014;26:356-369. doi: 10.1111/jne.12154.

5. Kim BK, Ozaki H, Hori M, Takahashi K, Karaki H. Increased contractility of rat uterine smooth muscle at the end of pregnancy. Comp Biochem Physiol A Mol Integr Physiol. 1998;121:165-173. doi: 10.1016/s1095-6433(98)10118-6.

6. Egawa M, Yasuda K, Nakajima T, Okada H, Yoshimura T, Yuri T, et al. smoking enhance oxytocin-induced rhythmic myometrial contraction. Biol Reprod. 2003;68:2274-2280. doi: 10.1095/biolreprod.102.010785

7. Kanamori C, Yasuda K, Sumi G, Kimura Y, Tsuzuki T, Cho $\mathrm{H}$, et al. effect of cigarette smoking on mRNA and protein levels of oxytocin receptor and on contractile sensitivity of uterine myometrium to oxytocin in pregnant women. Eur $J$ Obstet Gynecol. Reprod. Biol. 2014;178:142-147. doi: 10.1016/j.ejogrb.2014.03.037.

8. Nakamoto $T$, Katsuhiko $\mathrm{Y}$, Yasuhara M, Nakajima $\mathrm{T}$, Mizokami T, Okada H, et al. Cigarette smoke extract enhances oxytocin-induced rythmic contractions of rat and human preterm myometrium. Reproduction. 2006;132:343353. doi: 10.1530/rep.1.00908.
9. Cook JL, Randall CL. Acute ethanol exposure and premature parturition in C57BL/6J miceE: Aspirin antagonizes the effect. Alcohol Clin Exp Res. 1996;12, 123A.

10. Cook JL, Randall CL. Ethanol and parturition: a role for prostaglandins. Prostaglandins Leukot Essent Fatty Acids. 1998;58:135-142. doi: 10.1016/s0952-3278(98)90153-3.

11. Salo AL, Randall CL, Becker HC. Effect of acute ethanol and cocaine administration on gestation days 14-17 in mice. Alcohol. 1996;13:369-375. doi: 10.1016/07418329(96)00026-2.

12. Fuchs AR, Wagner G. Effect of alcohol on release of oxytocin. Nature. 1963;198:92-94. doi: 10.1038/198092b0.

13. Fuchs AR, Wagner G. The effect of ethyl alcohol on the release of oxytocin in rabbits. Acta Endocrinol (Copenh). 1963:44;593-605. doi: 10.1530/acta.0.0440593.

14. Cook JL, Randall CL. Early onset of parturition induced by acute alcohol exposure in C57BL/6J mice: role of uterine PGE and PGF2 $\alpha$. Reprod Fertil Dev. 1997;9;815-823. doi: 10.1071/r97083.

15. Wray S, Jones K, Kupittayanant S, Li Y, Matthew A, MonirBishty E, et al. Calcium signaling and uterine contractility. $J$ Soc Gynecol Investig. 2003;10:252-264. doi: 10.1016/s10715576(03)00089-3.

16. Xie Y, Garban H, Ng C, Rajfer J, Gonzalez-Cadavid NF. Effect of long-term passive smoking on erectile function and penile nitric oxide synthase in the rat. J. Urol. 1997;157:11211126.

17. Chan TC, Sutter MC. Ethanol consumption and blood pressure. Life Sci. 1983;33:1965-1973. doi: 10.1016/00243205(83)90734-8.

18. Cetin M, Kaya T, Cetin A, Sarioglu Y. Inhibitory effects of isradipine on spontaneous and oxytocin- and carbacholstimulated contractions of rat myometrium. Pharmacology. 1998;57:271-278. doi: 10.1159/000028251.

19. Kantas E, Cetin A, Kaya T, Cetin M. Effect of magnesium sulfate, isradipine, and ritodrine on contractions of myometrium: pregnant human and rat. Acta Obstet Gynecol Scand. 2002;81:825-830. doi: $10.1034 / \mathrm{j} .1600$ 0412.2002.810904.x.

20. Kimura T, Takemura M, Nomura S, Nobunaga T, Kubota Y, Inoue $\mathrm{T}$, et al. Expression of oxytocin receptor in human pregnant myometrium. Endocrinology. 1996;137:780-785. doi: 10.1210/endo.137.2.8593830.

21. Ivanisević M, Djelmis J, Buković D. Review on prostaglandin and oxytocin activity in preterm labor. Coll Antropol. 2001;25:687-694.

22. Hahn DW, McGuire JL, Vanderhoof M, Ericson E, Pasquale SA.. Evaluation of drugs for arrest of premature labor in a new animal model. Am. J Obstet Gynecol. 1984;148:775-778. doi: 10.1016/0002-9378(84)90565-9.

23. Maldaner FH, Durgante LP, Murussi M, Xavier MK, Dalmaz C, Ferreira MB.. Effects of chronic ethanol consumption on gestation and lactation in rats. Integr Physiol Behav Sci. 1994;29:141-150. doi: 10.1007/BF02691011.

24. Batra S. Increase by estrogen of calcium entry and calcium channel density in uterine smooth muscle. B J Pharmacol. 1987;92:389-392. doi: 10.1111/j.1476-5381.1987.tb11335.x

25. Kaya T, Cetin A, Cetin M, Sarioglu Y. Effects of nimodipine and isradipine on endothelin-1- induced contraction of pregnant rat myometrium. Eur. J. Pharmacol. 1998;346:6569. doi: 10.1016/s0014-2999(98)00140-x.

26. Besinger RE, Niebyl JR. The safety and efficacy of tocolytic agents for the treatment of preterm labor. Obstet Gynecol Surv. 1990;45:415-440. doi: 10.1097/00006254-19900700000002.

27. Thornton JG..Maintenance tocolysis. BJOG: an International Journal of Obstetrics and Gynaecology. 2005;112:118-121. doi:10.1111/j.1471-0528.2005.00599.x 